\author{
SURINAME ${ }^{1}$ ) \\ SOCIAAL-HYGIENISCHE BESCHOUWINGEN \\ DOOR
}

DR. P. H. J. LAMPE

I

DE NEDERLANDSCH-INDISCHE IMMIGRATIE IN SURINAME

(Uittreksel uit het derde gedeelte)

Het probleem, van welks oplossing algemeen een herstel van het ontwrichte Suriname wordt verwacht, is, hoe het productieven arbeid verrichtende gedeelte van de bevolking kan worden vergroot.

Slechts enkelen bepleiten een toename van het productieve element, door een meer oeconomische arbeidsverdeeling en een meer productieve arbeidsverrichting van de tegenwoordige bevolking.

Voor hen is het „Suriname Vraagstuk" gedeeltelijk een paedagogisch vraagstuk, waarbij de fouten, bij de emancipatie der slavan begaan, voor zooverre mogelijk, moeten worden hersteld; gedeeltelijk een technisch-kultureel vraagstuk, waarbij met een keuze van de juiste producten de vruchtbare bodem met eigen kracht zoo productief mogelijk moet worden gemaakt.

Meer algemeen wordt de oplossing gezocht in toename van het aantal productieve inwoners door immigratie en kolonisatie. Voor hen - die of wel alle illusies in de tegenwoordige bevolking verloren hebben, òf wel een onmiddellijk en tastbaar resultaat door middel van een massale toename van arbeidskrachten noodzakelijk achten - is het „Suriname Vraagstuk” een bevolkings-vraagstuk in den zin, die daaraan meer algemeen gegeven wordt.

1. Geslachtsverhouding, kinderverhouding

1) Uitgave van de Koninklijke Vereeniging „Koloniaal Instituut, Amsterdam".

West Indische Gids IX 
Een goed inzicht in het bevolkingsvraagstuk wordt verkregen, als wordt nagegaan:

a. de geslachtsverhouding van de volwassenen (boven 15 jaar);

$b$. de geslachtsverhouding van de kinderen (beneden 15 jaar);

c. de kinderverhouding (verhouding van het aantal kinderen beneden 15 jaar tot het aantal volwassenen boven 15 jaar).

Ten einde eenig inzicht hierin te verkrijgen is dit nagegaan van een aantal nederzettingen, uitsluitend bewoond door Inboorlingen, Britsch-Indiërs en Nederlandsch-Indiërs, met een totale bevolking van minstens 2000 zielen van iedere groep.

De uitkomsten van dit onderzoek waren als volgt:

TABEL 216

\begin{tabular}{|c|c|c|c|c|}
\hline & $\begin{array}{l}\text { Inboor- } \\
\text { lingen }\end{array}$ & $\begin{array}{l}\text { Britsch- } \\
\text { Indiërs }\end{array}$ & $\begin{array}{l}\text { Nederl.- } \\
\text { Indiërs }\end{array}$ & $\begin{array}{c}\text { Totale } \\
\text { Bevolking }\end{array}$ \\
\hline $\begin{array}{l}\text { Geslechtsverhouding: } \\
\text { volwassenen . . . . } \\
\text { kinderen . . . . . } \\
\text { totaal . . . . . . . } \\
\text { Kinderverhouding. . . . }\end{array}$ & $\left|\begin{array}{cc}\text { M. } & \text { V. } \\
1000: & 934 \\
1000: & 882 \\
1000: & 914 \\
601: & 1000\end{array}\right|$ & $\begin{array}{c}\text { M. V. } \\
1000: 713 \\
1000: 794 \\
1000: 741 \\
637: 1000\end{array}$ & $\begin{aligned} \text { M. } & \text { V. } \\
1000: & 658 \\
1000: & 861 \\
1000: & 705 \\
348: & 1000\end{aligned}$ & $\begin{array}{r}\text { M. } \\
1000: 8 . \\
1000: 950 \\
1000: 910 \\
487: 1000\end{array}$ \\
\hline
\end{tabular}

Van de Nederlandsch-Indische „contracten" was de geslachtsverhouding op 1 Juli 1926:

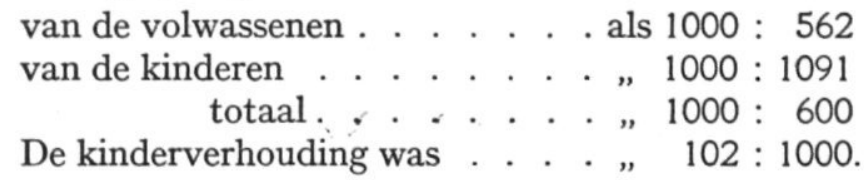

Bij de vergelijking van de in tabel 216 genoemde verhoudingen blijkt:

1. dat het aantal volwassen mannen in de nederzettingen, door Inboorlingen bewoond, slechts weinig grooter is dan het aantal volwassen vrouwen;

2. dat in de Britsch-Indische en meer nog in de NederlandschIndische nederzettingen het vrouwen-tekort zeer belangrijk is;

3. dat het aantal kinderen, vergeleken met het aantal volwassenen het grootst is in de Britsch-Indische nederzettingen;

4. dat het aantal kinderen in vergelijking met het aantal volwassenen op de Nederlandsch-Indische nederzettingen slechts ruim half zoo groot is als op de Britsch-Indische nederzettingen. 


\section{Vruchtbaarheids-coëfficient, opgroei-coëfficient.}

Onder vruchtbaarheids-coëfficient wordt verstaan het gemiddeld aantal voldragen kinderen, dat door de vrouwen ter wereld wordt gebracht.

Onder opgroei-coëfficient wordt verstaan het gemiddeld aantal kinderen, dat - per vrouw - den leeftijd van 15 jaar bereikt, of dat ten tijde van het onderzoek nog in leven is. Teneinde dit te berekenen werd een aantal Inlandsche vrouwen, Britsch-Indische vrouwen en Nederlandsch-Indische vrouwen, die den leeftijd van het klimacterium bereikt hadden, hieromtrent ondervraagd. Belangrijke gegevens konden verder nog verzameld worden uit de registers van het immigratie-departement. De ondervraagden werden zoo willekeurig mogelijk gekozen, het onderzochte aantal bedroeg minstens 200 van iedere groep.

De uitkomsten van dit onderzoek waren als volgt:

TABEL 217

\begin{tabular}{|c|c|c|}
\hline & $\begin{array}{l}\text { Vruchtbaarheids- } \\
\text { coefficient }\end{array}$ & $\begin{array}{l}\text { Opgroei- } \\
\text { coefficient }\end{array}$ \\
\hline Inlandsche bevolking & 6.3 & 3.6 \\
\hline Britsch-Indische bevolking . . & 2.6 & 2.3 \\
\hline Nederlandsch-Indische bevolking & 1.2 & 0.7 \\
\hline Geheele bevolking (naar schatting) & 4.4 & 2.7 \\
\hline
\end{tabular}

Bij de Inlandsche bevolking is de vruchtbaarheids-coëfficient van de vrouwen buitengewoon groot (6.3); tengevolge van de groote sterfte is de opgroei-coëfficient zeer veel kleiner (3.6).

Bij de Britsch-Indische bevolking is de vruchtbaarheids-coëfficient veel kleiner (2.6); tengevolge van de geringe sterfte is de opgroei-coëfficient nog betrekkelijk groot (2.3).

Bij de Nederlandsch-Indische bevolking bedraagt de vruchtbaarheids-coëfficient slechts 1.2 en de opgroei-coëfficient slechts 0.7 .

Hieraan kan nog het volgende worden toegevoegd, om de toestanden op de plantages te schetsen.

Op twee groote plantages in Suriname, waar de hygiënische toestanden zeker niet slechter zijn dan op de overige plantages en waar met name zorg wordt besteed aan zwangere vrouwen en jonge moeders en kinderen (geregeld onderzoek, vrijstelling van arbeid enz.), was het aantal geboorten en de kindersterfte als volgt: 
Op een gemiddeld aantal Javaansche vrouwen van $15-45$ jaar, respectievelijk op de beide plantages, groot 495 en 308, werden in tien jaren tijds (1916-1925) totaal geboren 443 en 302 kinderen, dit wil zeggen nog niet één kind per vrouw van 15-45 jaar in 10 jaren tijds.

Van de 443 kinderen overleden 86 kinderen in hetzelfde jaar van de geboorte, dit is 194 per 1000 geborenen.

Van de 302 kinderen overleden 75 kinderen in hetzelfde jaar van de geboorte, dit is 249 per 1000 geborenen.

3. Onderzoek van Ioo willekeurige Inlandsch-, Britsch-Indische en Nederlandsch-Indische vrouwen, ouder dan 45 jaar, naar het aantal voldragen kinderen, dat zij gebaard hebben en naar het aantal kinderen, dat ten tijde van het onderzoek nog in leven was. (Zie graphiek XXXIII en XXXIV).

TABEL 218

A. AANTAL KINDEREN, DAT TER WERELD IS GEBRACHT

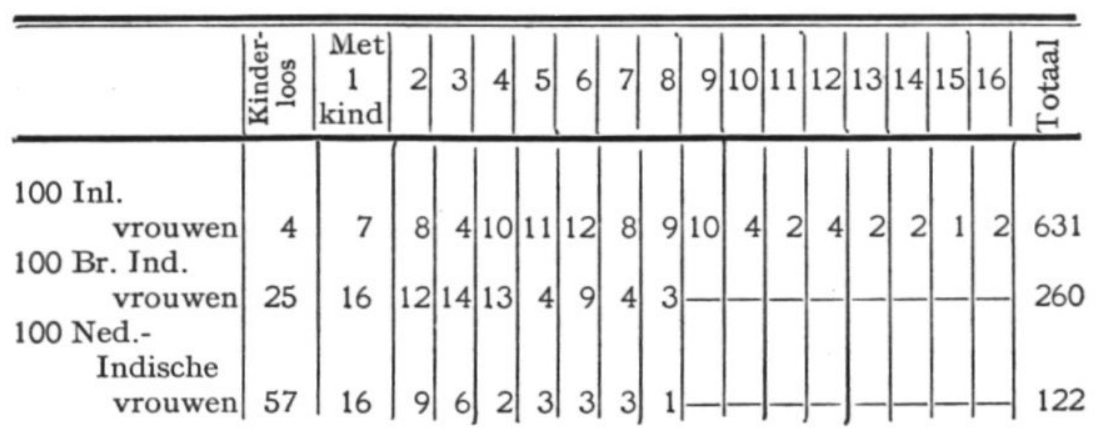

B, AANTAL KINDEREN, DAT OVERLEDEN WAS

\begin{tabular}{|c|c|c|c|c|c|c|c|c|c|c|c|c|c|c|}
\hline & 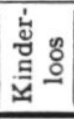 & $\left|\begin{array}{c}\text { Verlies } \\
\text { van } \\
0\end{array}\right|$ & $\begin{array}{c}\begin{array}{c}\text { Verlies } \\
\text { van } \\
1\end{array} \\
\end{array}$ & 2 & $|3|$ & 4 & & 6 & 7 & 8 & $9 \mid 10$ & 11 & 12 & \\
\hline $\begin{array}{l}100 \mathrm{Inl} \text {.vrouwen } \\
100 \mathrm{Br} \text {.-Ind. }\end{array}$ & 4 & 21 & 18 & 13 & 121 & & 84 & 4 & 3 & 2 & 2 & 2 & & 265 \\
\hline $\begin{array}{r}\text { vrouwen } \\
100 \text { Ned.Indische } \\
\text { vrouwen }\end{array}$ & $\begin{array}{l}25 \\
57\end{array}$ & $\begin{array}{l}48 \\
11\end{array}$ & $\begin{array}{l}19 \\
20\end{array}$ & 8 & 2 & & & & & & & & & $\begin{array}{l}35 \\
52\end{array}$ \\
\hline
\end{tabular}

De resultaten van dit onderzoek zijn geheel in overeenstemming met de vruchtbaarheids- en opgroei-coëfficient van de verschillende rassen in Suriname, zooals vermeld op blz. 467. 


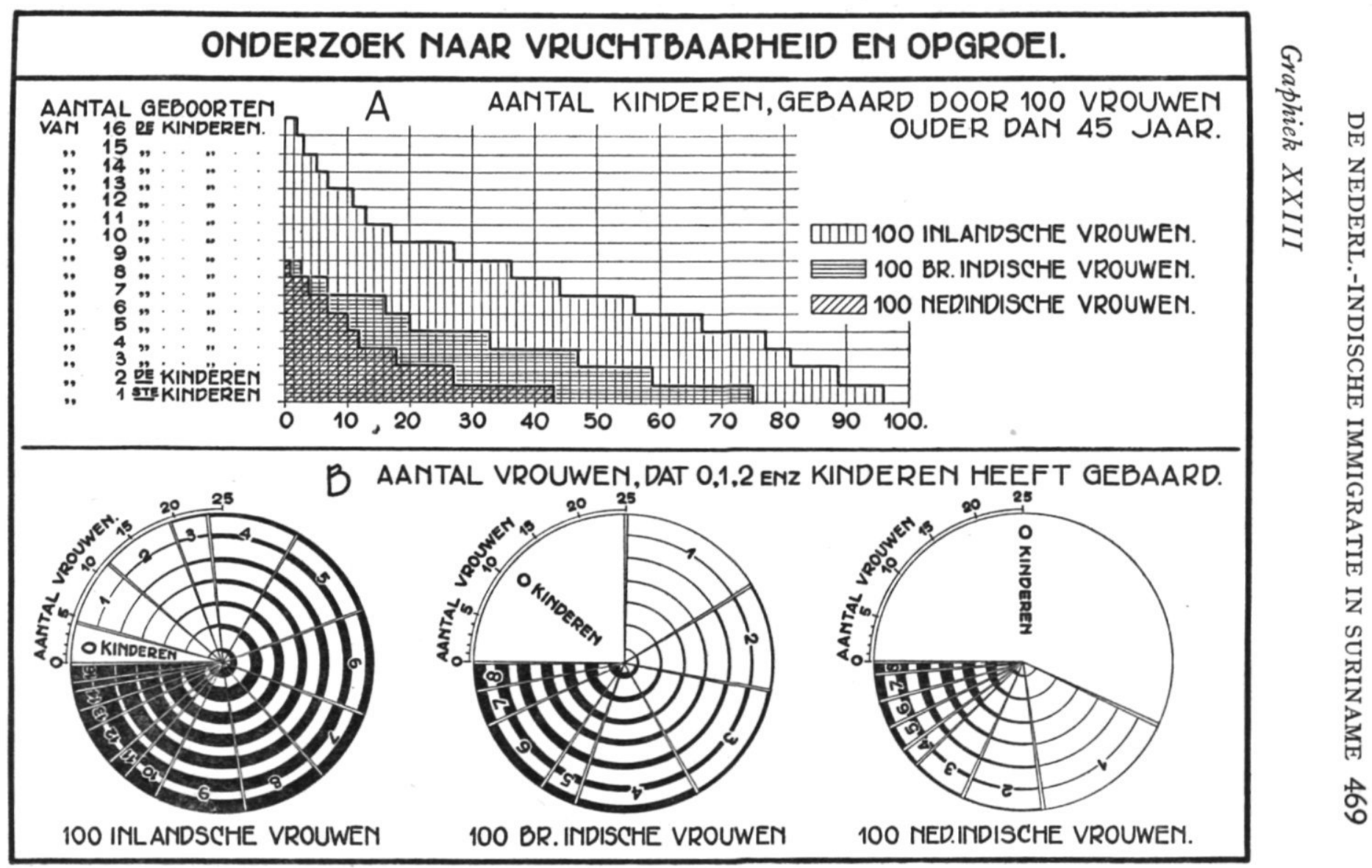




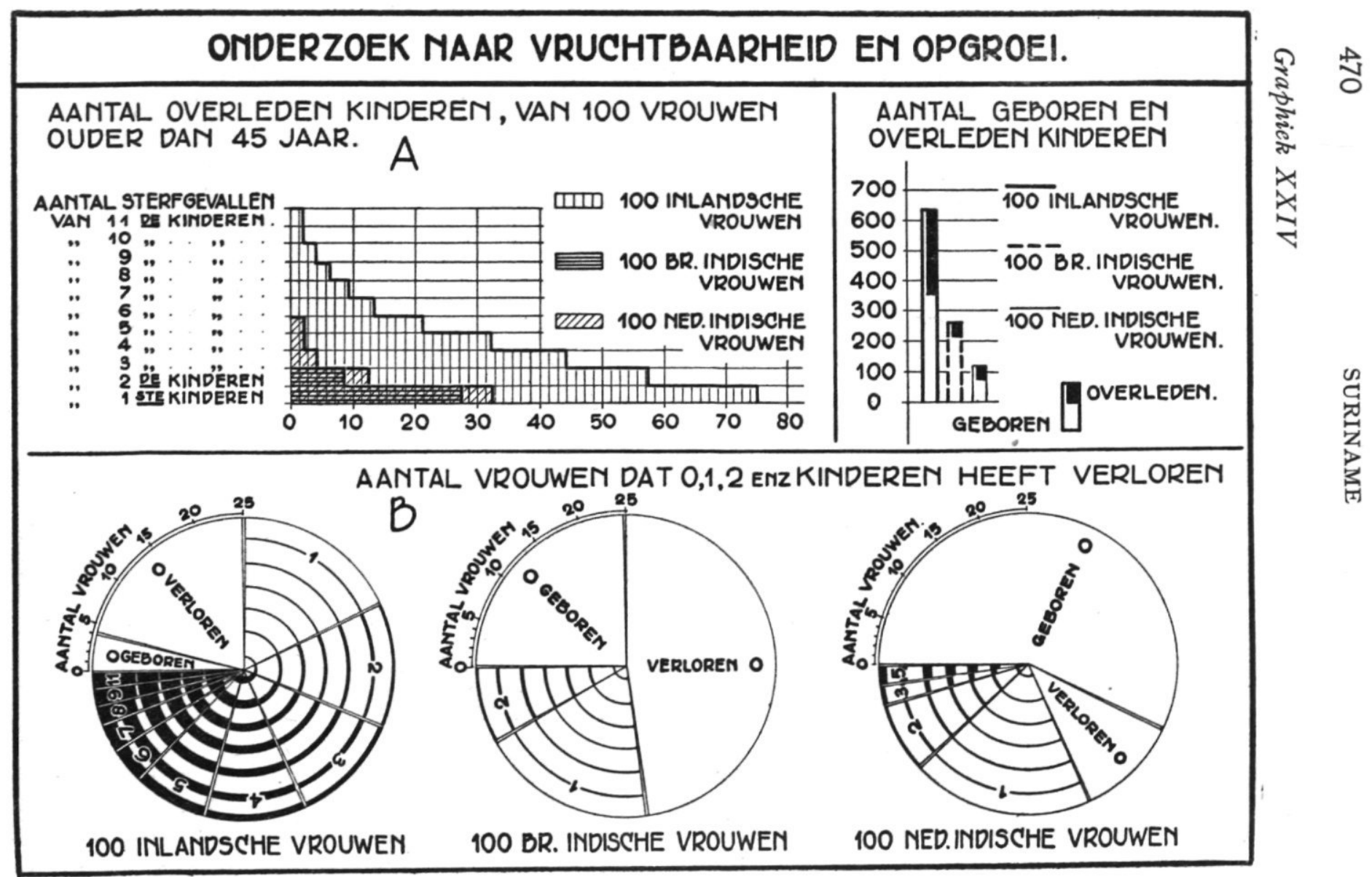


Bijzondere aandacht verdient:

1. het percentage vrouwen, dat kinderloos blijft:

bij de Inlandsche vrouwen . . . . . . . . $4 \%$,

bij de Britsch-Indische vrouwen . . . . . $25 \%$,

bij de Nederlandsch-Indische vrouwen . . . $57 \%$ !!!!

2. het percentage vrouwen, dat slechts óén kind krijgt:

bij de Inlandsche vrouwen . . . . . . . . $7 \%$,

bij de Britsch-Indische vrouwen . . . . . $16 \%$,

bij de Nederlandsch-Indische vrouwen . . . $16 \%$;

3 . het verloop van de curve, voorstellende het aantal vrouwen dat respectievelijk 0, 1, 2, 3, enz. kinderen krijgt (zie graphiek XXXIII);

4. de groote sterfte van Inlandsche kinderen en Nederlandsch-Indische kinderen (zie graphiek XXXIV);

5. de geringe sterfte van Britsch-Indische kinderen.

4. Samenvatting en conclusies.

TABEL 219

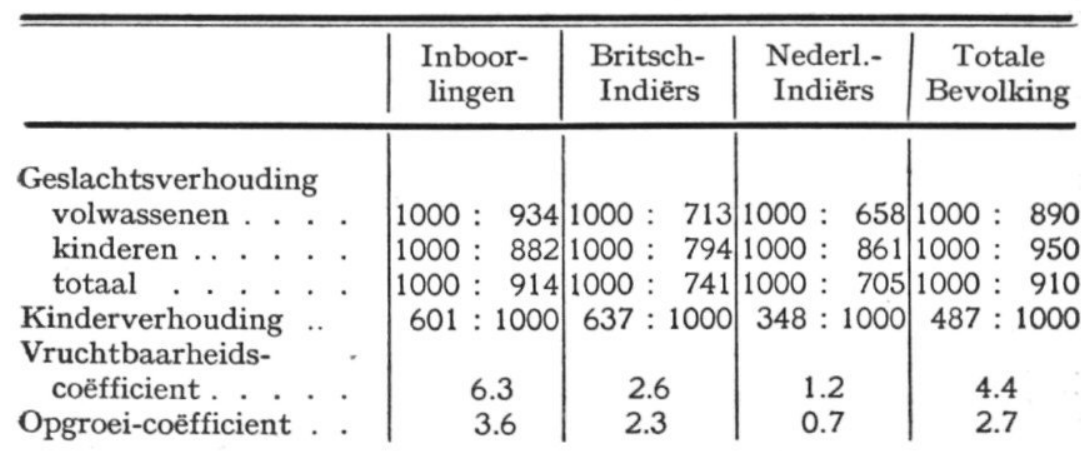

De opgroei per 1000 volwassenen bedraagt:

bij de Inboorlingen . . . . . . . . . $3477^{1}$ )

bij de Britsch-Indiërs . . . . . . . . 1891

bij de Nederlandsch-Indiërs . . . . 555

Volgens Kulz (,Zur Biologie und Pathologie des Nachwuchses bei den Naturvolkern" - Leipzig, 1919) kan men in verband met de opgroei-coëfficient drie typen onderscheiden, namelijk;

1) Op 1000 vrouwen boven 15 jaar bedraagt de opgroei . . . . 3600

Op 1934 volwassenen boven 15 jaar (1000 mannen +934 vrouwen): $\frac{2 \times 934}{1000} \times 3600$

Op 1000 volwassenen boven 15 jaar. $\frac{2 \times 934}{1934} \times 3600$ d.i. 3477 
a. Type I, de opgroei per 1000 volwassenen bedraagt 1000;

$b$. Type II, de opgroei per 1000 volwassenen is kleiner dan 1000 ;

c. Type III, de opgroei per 1000 volwassenen is grooter dan 1000 .

Een bevolking met een bevolkingsaanwas volgens type I blijft op dezelfde sterkte; een bevolking volgens type II gaat te gronde een bevolking volgens type III vermeerdert.

Opgrond van de bovenvermelde gegevens moet worden aangenomen, dat de Inlandsche bevolking zal blijven toenemen, evenals de BritschIndische bevolking (type III) en dat de Nederlandsch-Indische bevolking in Suriname - aan zichzelve overgelaten - op den duur te gronde zal gaan ${ }^{\mathbf{1}}$.

De invloed van de immigratie - waarbij bij voorkeur vrouwen zonder kinderen worden aangenomen - is te gering om deze uitkomst ook maar eenigszins te beinvloeden.

Alvorens dit vernietigend oordeel uit te spreken, is het wel aangewezen om aan een grooter materiaal de bovenomschreven uitkomsten nog eens te toetsen, al kan zeer zeker worden aangenomen, dat de verschillen uiterst gering zullen zijn (zie ook tabel 216 en 217).

§ III. Het lot van een transport Nederlandsch-Indische en BritschIndische immigranten van I899 en I9oo (gegevens van het Immigratie-Departement)

In 1900 kwamen 930Nederlandsch-Indische mannen, ouder dan 15 jaar, als contractanten in Suriname aan.

1) Deze uitspraak is gebaseerd op de uitkomsten van een aantal onderzoekingen van uit Ned.-Indië aangevoerde immigranten.

Mogelijk is, dat de opgroei van een tweede,derde of latere - in Suriname geboren - generatie voldoende zal zijn, om dit ras dan in stand te houden.

Het rekenen op deze mogelijkheid, die ten overvloede nog geenszins eenige zekerheid biedt, kan evenwel nimmer als basis bedoeld zijn van de plannen, om door immigratie te komen tot kolonisatie, in een zoo kort mogelijken termijn.

Aannemende, dat de opgroei uit het eerste in Suriname geboren geslacht Nederlandsch-Indiërs voldoende zal zijn, beteekent dat, dat de verwachte opgroei eerst na verloop van een gemiddelden menschenleeftijd een aanvang neemt en dan uitgaande van een inmiddels gehalveerde stam (de opgroei per 1000 volwassenen bedraagt nu slechts 500 ).

Het is wel van belang hier nogmaals op te merken, dat de opgroei van de uit Britsch-Indië aangevoerde immigranten van meet af aan ruimschoots voldoende is geweest (de opgroei per 1000 volwassenen - uit Britsch-Indië aangevoerd - bedroeg ongeveer 2000). 
Bij het naslaan van de registers van het Immigratie-Departement in September 1926 bleek, dat van deze mannen 309 mannen vertrokken waren naar Oost-Indië (na afloop van contract of her-contract); dat 22 mannen nog gecontracteerd waren (hercontracten); dat 286 mannen in Suriname overleden waren; dat 56 mannen een perceel in huur of eigendom hadden van het gouvernement; dat 257 mannen met een certificaat van ontslag nog in Suriname aanwezig waren.

In 1899 kwamen 396 Britsch-Indische mannen, ouder dan 15 jaar, als contractanten in Suriname aan.

Stand in September 1926: 133 mannen vertrokken naar Britsch Indië; 85 mannen overleden in Suriname; 40 mannen een perceel in eigendom of huur van het gouvernement; 139 mannen met een certificaat van ontslag nog in Suriname aanwezig.

In 1900 kwamen 381 Nederlandsch-Indische vrouwen, ouder dan 15 jaar, als contractanten in Suriname aan.

Stand in September 1926: 102 vrouwen vertrokken naar Oostdië; 95 vrouwen overleden in Suriname; de 184 Nederlandsch-Indische vrouwen van dat transport, die nu nog in Suriname in leven zijn, hebben te zamen 221 kinderen ter wereld gebracht, waarvan er nu nog 134 in leven zijn; van die 184 vrouwen zijn 100 vrouwen kinderloos gebleven en 29 vrouwen kregen niet meer dan één kind.

In 1899 kwamen 150 Britsch-Indische vrouwen, ouder dan 15 jaar, als contractanten in Suriname aan.

Stand in September 1926: 26 vrouwen vertrokken naar BritschIndië, 38 vrouwen overleden in Suriname; de 86 Britsch-Indische vrouwen van dat transport, die nu nog in Suriname in leven zijn, hebben te zamen 195 kinderen ter wereld gebracht, waarvan er nu nog 161 in leven zijn; van die 86 vrouwen zijn 28 vrouwen kinderloos gebleven en 14 vrouwen kregen niet meer dan één kind.

Ter onderlinge vergelijking zijn in tabel 220 deze gegevens in percenten uitgedrukt: 
TABEL 220

\begin{tabular}{|c|c|c|}
\hline $\begin{array}{c}\text { Registratie in Sept. } \\
1926\end{array}$ & $\begin{array}{l}\text { Nederlandsch-Ind. } \\
\text { contractanten, man- } \\
\text { nen ouder dan } 15 \text { jaar. } \\
\text { Transport } 1900\end{array}$ & $\begin{array}{c}\text { Britsch-Indische } \\
\text { contractanten, man- } \\
\text { nen ouder dan } 15 \text { jaar. } \\
\text { Transport } 1899\end{array}$ \\
\hline $\begin{array}{l}\text { Teruggekeerd naar } \\
\text { Ned. of Britsch-Indië }\end{array}$ & $\begin{array}{l}33.6 \% \text { van het totaal } \\
\text { aantal aangeko- } \\
\text { menen }\end{array}$ & $\begin{array}{l}33.0 \% \text { van het totaal } \\
\text { aantal aangeko- } \\
\text { menen }\end{array}$ \\
\hline $\begin{array}{l}\text { Overleden in Suriname } \\
\text { Nog gecontracteerd.. }\end{array}$ & $\begin{array}{c}46.5 \% \text { van de niet ge- } \\
\text { repatrieerden } \\
3.6 \% \text { van de niet ge- } \\
\text { repatrieerden }\end{array}$ & $\begin{array}{l}32.2 \% \text { van de niet ge- } \\
\text { repatrieerden } \\
-.-\% \text { van de niet ge- } \\
\text { repatrieerden }\end{array}$ \\
\hline $\begin{array}{r}\text { Perceel van het gouver } \\
\text { nement in eigendom }\end{array}$ & & \\
\hline of huur . . . . & $\begin{array}{c}9.1 \% \text { van de niet ge- } \\
\text { repatrieerden }\end{array}$ & $\begin{array}{l}15.2 \% \text { van de niet ge- } \\
\text { repatrieerden }\end{array}$ \\
\hline Met certificaat v. ontsl. & $\begin{array}{c}40.8 \% \text { van de niet ge- } \\
\text { repatrieerden }\end{array}$ & $\begin{array}{l}52.6 \% \text { van de niet ge- } \\
\text { repatrieerden }\end{array}$ \\
\hline Totaal . . . . & $\begin{array}{c}100 \% \text { van de niet ge- } \\
\text { repatrieerden }\end{array}$ & $\begin{array}{c}100 \% \text { van de niet ge- } \\
\text { repatrieerden }\end{array}$ \\
\hline $\begin{array}{l}\text { Registratie in Sept. } \\
1926\end{array}$ & $\begin{array}{l}\text { Nederlandsch-Ind. } \\
\text { contractanten, vrou- } \\
\text { wen ouder dan } 15 \text { jaar. } \\
\text { Transport } 1900\end{array}$ & $\begin{array}{c}\text { Britsch-Indische } \\
\text { contractanten, vrou- } \\
\text { wen ouder dan } 15 \text { jaar. } \\
\text { Transport } 1899\end{array}$ \\
\hline \multirow{2}{*}{$\begin{array}{l}\text { Teruggekeerd naar } \\
\text { Ned. of Bıitsch-Indië }\end{array}$} & & \\
\hline & $\begin{array}{c}26.8 \% \text { van het totaal } \\
\text { aantal aangeko- } \\
\text { menen }\end{array}$ & $\begin{array}{l}17.3 \% \text { van het totaal } \\
\text { aantal aangeko- } \\
\text { menen }\end{array}$ \\
\hline Overleden in Suriname & $\begin{array}{c}34.1 \% \text { van de niet ge- } \\
\text { repatrieerden }\end{array}$ & $\begin{array}{c}30.6 \% \text { van de niet ge- } \\
\text { repatrieerden }\end{array}$ \\
\hline $\begin{array}{l}\text { Aantal geboorten per } \\
100 \text { vrouwen . } \cdot \text {. } \\
\text { Aantal kinderen nog in }\end{array}$ & 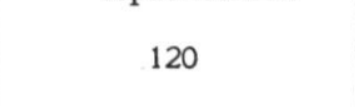 & 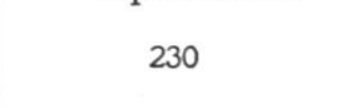 \\
\hline $\begin{array}{l}\text { leven per } 100 \text { vrou- } \\
\text { wen }\end{array}$ & 73 & 187 \\
\hline $\begin{array}{l}\text { Aantal kinderlooze v1. } \\
\text { per } 100 \text { vrouwen. } \\
\text { Aantal vrouwen met }\end{array}$ & 54 & 33 \\
\hline $\begin{array}{l}\text { één kind per } 100 \text { vrou- } \\
\text { wen }\end{array}$ & 16 & 16 \\
\hline
\end{tabular}

De belangrijkste verschillen zijn:

1. De grootere emigratie van de Nederlandsch-Indiërs, vooral 
van de vrouwen. Van de Nederlandsch-Indische vrouwen is $27 \%$, van de Britsch-Indische vrouwen $17 \%$ gerepatrieerd.

2. De grootere sterfte van de achtergebleven NederlandschIndiërs in Suriname, vooral van de mannen. Van de Nederlandsch-Indische mannen is $46 \%$ en van de Nederlandsch-Indische vrouwen is $34 \%$ overleden. Bij de Britsch-Indische mannen, en vrouwen bedraagt dit respectievelijk $32 \%$ en $31 \%$.

3. De geringe vruchtbaarheids-coëfficient van de Nederlandsch-Indische vrouwen, namelijk 1.2. in tegenstelling met de grootere vruchtbaarheids-coëfficient van de Britsch-Indische vrouwen, namelijk 2.3 .

4. De geringe opgroei-coefficient van de Nederlandsch-Indische vrouwen, namelijk 0.73 , in tegenstelling met de grootere opgroeicoëfficient van de Britsch-Indische vrouwen, namelijk 1.87.

5. Het groote aantal Nederlandsch-Indische vrouwen, dat geen kinderen krijgt, namelijk $54 \%$, in tegenstelling met het kleinere percentage van de Britsch-Indische vrouwen, namelijk $33 \%$.

Ook dit onderzoek naar het lot van een transport NederlandschIndische immigranten dwingt wederom tot het constateeren van het ontstellende feit:

dat de opgroei van dit ras in Suriname verre van voldoende is, om gehandhaafd te blijven,

dat de Nederlandsch-Indische bevolking in Suriname, aan zich zelve overgelaten - zonder verdere immigratie dus - gedoemd is op den duur geheel te verdwijnen en dat in betrekkelijk korten tijd. (Zie noot blz. 472).

$\S$ IV. Welke maatregelen zijn noodig, om een fataal einde van de door de regeering opgezette onderneming te voorkomen?

De onvoldoende opgroei van het Nederlandsch-Indische ras in Suriname wordt veroorzaakt door:

1. Het gering aantal geboorten.

2. Het groot aantal levenloosgeborenen en de groote kindersterfte.

1. Het gering aantal geboorten:

Behalve het vrouwen-tekort spelen twee factoren hier een belangrijke rol, namelijk:

a. steriliteit, tengevolge van geslachtsziekten (gonorrhoe);

$b$. kunstmatige verhindering van conceptie en vruchtafdrijving. 
$a$. In zeer vele gevallen moet de geringe vruchtbaarheid van de Javaansche vrouwen verklaard worden als gevolg van venerische besmettingen, vooral van gonorrhoe. Deze laatste ziekte is opvallend frequent bij mannen en vrouwen, heerscht soms zelfs epidemisch op de plantages. Bij de heerschende gebruiken, de slechte gezinsvorming, het kortdurend samenwonen van man en vrouw en de herhaalde wisselingen, die hiervan het gevolg zijn, kan het ook niet anders of iedere besmetting vormt een haard van nieuwe besmettingen. Deze steriliteit - voor zooverre veroorzaakt door gonorrhoe - is meestal blijvend en daarom van verstrekkende gevolgen.

$b$. Het is zeer moeilijk, zoo niet onmogelijk, de noodlottige gevolgen van den anderen factor - kunstmatige verhindering van conceptie en vruchtafdrijving - afzonderlijk te schatten. De Javaansche vrouwen zijn over het algemeen weinig mededeelzaam, vooral wat betreft deze aangelegenheden.

Volgens sommige kenners van Javaansche gebruiken zouden kunstgrepen worden toegepast, waardoor blijvende steriliteit kan ontstaan. Als zij later van inzicht veranderen is de fout onherstelbaar. Persoonlijk heb ik eenige malen meegemaakt, dat vrouwen, die zeker meenen te weten om die reden nimmer moeder te kunnen worden, verzoeken de verzorging van een ander kind op zich te mogen nemen.

Massage zou hier o.a. een rol spelen, waardoor liggingsanomalieën van de uterus, ontstekingen en vergroeiingen optreden. Ik weet niet of die inlichtingen voldoende betrouwbaar zijn, evenmin of het mogelijk is, dat door dergelijke kunstgrepen steriliteit (blijvende) zou kunnen ontstaan. Wel staat vast, dat het percentage liggingsanomalieën van de uterus bij de Javaansche vrouwen in Suriname opvallend hoog is.

Andere praktijken, die ook wel genoemd worden, ga ik stilzwijgend voorbij. Het voornaamste is, dat vele Javaansche vrouwen wenschen kinderloos te blijven en daartoe niet nader bekende kunstgrepen toepassen of dulden ${ }^{1}$ ).

In tegenstelling met deze min of meer vage kennis, betreffende de kunstmatige verhindering van de conceptie, is het van algemeene bekendheid, dat de Javaansche vrouwen met een ware vir-

$\left.{ }^{1}\right)$ Volgens Stratz is de overgroote menigte der retroversies bij Javaansche vrouwen een kunstproduct, ontstaan door manupilaties der Inlandsche wijze vrouwen (Doekoe), met opzet tot stand gebracht om steriliteit te verwekken. Stratz, Dr. C. H. - De vrouwen van Java - Een gynaecologische studie, Amsterdam, 1897. 
tuositeit de kunstmatige vruchtafdrijving beoefenen. Over de in zwang zijnde methoden behoeft hier niet nader uitgewijd te worden.

In zeer vele gevallen zijn de Javaansche vrouwen reeds bij aankomst in Suriname - voor de tewerkstelling op de plantages tot voortplanting ongeschikt. Een specialistisch onderzoek van pas aangekomen Javaansche contractanten heeft dit nader aangetoond (nadere bijzonderheden hieromtrent worden in dit resumé weggelaten).

Het zijn dié contractanten, die misschien zeer bruikbare krachten zijn voor de plantages, maar die voor de kolonie Suriname van geen waarde zijn. De poging van de regeering om door aanvoer van veel vrouwen (het laatste transport bestond voor ongeveer twee-derde gedeelte uit vrouwen) te komen tot vruchtbare kolonisatie en opgroei van het Javaansche ras in Suriname is dan toch tot mislukking gedoemd.

\section{Het groot aantal levenloosgeborenen en de groote kindersterfte.}

Het groot aantal levenloosgeborenen hangt samen met ziekten van de moeder, zooals in de eerste plaats syphilis en verder malaria en nephritis. De groote kindersterfte wordt veroorzaakt door syphilis (aangeboren zwakte en gebreken), malaria (nephritis), longaandoeningen en ingewandsaandoeningen. Longaandoeningen en ingewandsaandoeningen hangen ten nauwste samen met de verzorging van het kind en dit is weer voor een groot deel afhankelijk van de bestaande gezinsverhoudingen. In het kort samengevat, moeten dus als oorzaken van de groote kindersterfte genoemd worden de slechte gezinsverhoudingen, de venerische infecties en de malaria.

\section{Welke maatregelen moeten genomen worden?}

Uit het voorgaande volgt, dat de beantwoording van de bovengestelde vraag neerkomt op bestrijdingsmaatregelen van:

De veelvuldig voorkomende venerische infecties,

De slechte gezinsvorming,

De wensch van vele vrouwen om kinderloos te blijven.

De dessa-bevolking in de Oost is niet sterk, soms weinig, soms in het geheel niet besmet. Het gevaar treedt op bij het verkeer in groote steden, gedurende het verblijf in de dépôts vóór het trans- 
port, gedurende het transport, gedurende het verblijf in de dépôts na het transport en niet het minst tijdens het verblijf op de plantages. Een zeer belangrijke factor is verder het vrouwen-tekort, de slechte gezinsvorming en de talrijke wisselingen daarin als immigrant en kolonist. De bestrijding moet dus eigenlijk reeds in de Oost beginnen. Strenge selectie van emigranten, liefst uitsluitend dessabevolking en streng toezicht gedurende het verblijf in de dépôts en gedurende het transport.

Dat een strenge selectie van de Javaansche vrouwen, die zich laten aanwerven, geen overbodige weelde is, volgt wel uit. de resultaten van het onderzoek van pas aangekomen contractanten, in het voorgaande vermeld. De meerdere kosten van een streng specialistisch onderzoek behoeven natuurlijk niet eens overwogen te worden.

Veel moeilijker werk wacht na aankomst op de plantages. Aan het vrouwen-tekort wordt nu reeds aandacht besteed, maar de gezinsvorming en de gezinsinstandhouding, die hier moet worden opgezet en hier blijken moet geven van standvastigheid, zal steeds - ook na strenge selectie in de Oost - talrijke slachtoffers eischen, slachtoffers, die blijven zoeken en probeeren, ook bij de reeds aanwezige rasgenooten; die zich besmetten, omdat die kans niet is te ontgaan en die op hun of haar beurt bronnen vormen van nieuwe besmettingen, waarvan de gevolgen niet te overzien zijn.

Beter zou het zijn, als het proces van de gezinsvorming zich afspeelde in Oost-Indië, waar het minder gevaren oplevert, zoolang het blijft in het kringetje van de dessa. Immigratie van gevormde gezinnen, die waarborgen gegeven hebben van duurzaamheid, liefst met één of meer kinderen, zou de bovengenoemde gevaren kunnen bezweren. Bovendien ontgaat men dan de kans geheel, dat Suriname bevolkt wordt met een categorie van vrouwen, die geen kinderen kunnen krijgen of geen kinderen wenschen te hebben; die, of wel tengevolge van een doorstane venerische besmetting, of wel moedwillig zich zelf (voor altijd) steriel gemaakt hebben.

De grootere kosten, die een immigratie van Javaansche gezinnen met zich zou brengen, omdat deze zedelijk hoogerstaande individuen minder dikwijls door socialen nood of sociale vergrijpen hiertoe gedwongen worden, zullen ruimschoots vergoed worden, omdat dan de immigratie zeker zal beantwoorden aan haar doel, namelijk het tot stand brengen van een nieuw ras kleine landbouwers in Suriname. 
Hieraan annex een verbetering van de woningtoestanden, een streng toezicht op de gezinsverhoudingen, verplichte aangifte van beginnende besmettingen, een goed doorgevoerde behandeling. . en goede resultaten zullen niet uitblijven.

Uit deze immigranten worden de kolonisten gerecruteerd. Zoo voorbereid zullen ook de kolonisten minder moeilijkheden geven en zullen bij de kolonisten minder ingrijpende maatregelen noodzakelijk zijn. Maar ook bij de vrije immigranten blijft waakzaamheid geboden.

Voorzoover nog aan de plantages verbonden, moeten zij zich onderwerpen aan de verplichtingen, die zij van hun contractantentijd kennen. Op de nederzettingen, waar misschien niet alles in denzelfden geest is door te voeren - verplichte aangifte vooral zal moeilijk zijn - zal men dan moeten volstaan met toezicht, contrôle, propaganda en individueele behandeling.

Resumeerende blijkt dus, dat in ieder geval hoogst noodzakelijk is een zeer strenge selectie van de immigranten in Oost-Indië (bij voorkeur uitsluitend dessabevolking). Vooraf stelle men zich op de hoogte van de mentaliteit van de vrouwen. Men zoeke slechts in kringen, waar de verderfelijke praktijken van moedwillig opgewekte steriliteit nog niet zijn doorgedrongen. Een nauwkeurig specialistisch onderzoek is absoluut noodzakelijk en alle eenigszins verdachte gevallen (liggingsanomalieën van de uterus, salpingitiden, parametriden, enz. enz.) moeten onvoorwaardelijk worden geweigerd. Noodig is verder streng toezicht in de dépôts en gedurende het transport op de schepen. Het verkeer van mannen en vrouwen moet niet afhankelijk zijn van het verantwoordelijkheidsgevoel van opzichters, maar „absoluut onmogelijk” zijn. Op de plantages is een verbetering van de woningtoestanden gewenscht; verder streng toezicht op de gezinsverhoudingen (invoering van een burgerlijken stand?) om het proces van de gezinsvorming met zoo weinig mogelijk nadeelen te doen verloopen; verplichte aangifte van venerische infecties en streng doorgevoerde behandeling. Geregelde kinderinspecties op de plantages (geen sleur, maar geregeld zoeken naar bepaalde indices, miltindex, parasietenindex, bloedgehalte, enz.), verzorging van kleine kinderen gedurende den werktijd van de moeders in een daartoe bestemde ruimte onder toezicht van een geschikt persoon en dergelijke maatregelen meer zullen de kindersterfte drukken. Verder zou het misschien overweging verdienen door het stellen van kinderpremies de vrouwen op te wekken tot het verkrijgen van meer kinderen. In denzelfden geest werken nog andere kleine 
maatregelen, zooals extra-voeding en lichte werkzaamheden van zwangeren en jonge moeders zonder loonsvermindering, enz. enz.

Zeer veel nader zou men komen tot het gestelde doel van de immigratie, als kon worden overgegaan tot immigratie van Javaansche gezinnen, die reeds blijken hebben gegeven van duurzaamheid, die getoond hebben niet afkeerig te zijn van kinderen en die in staat zijn kinderen te krijgen. De hoogere eischen, die deze gezinnen zullen stellen om naar hier te immigreeren, zullen misschien geen te groot bezwaar zijn, omdat zij zeker goede resultaten zullen waarborgen ${ }^{1}$ ). De meest ideale toestand zou zijn, als groepen van gezinnen met kinderen, afkomstig uit dezelfde dessa, na blijken te hebben gegeven hier te zullen voldoen, konden worden overgehaald zich in Suriname te vestigen als contractanten of kolonisten. Als één geheel overgebracht op geschikte plantages of met veel steun en tegemoetkoming van het gouvernement geplaatst op goede vestingsplaatsen, zouden deze kolonies een uitgangspunt vormen voor een succesvolle kolonisatie, tevens misschien een voorbeeld zijn voor rasgenooten, die nog voor verbetering vatbaar zijn.

1) Ook reeds vroeger is ingezien, dat een eventueele gezinswerving het gehalte en het nuttig effect van de aangevoerde immigranten zou kunnen verbeteren.

Volgens een missive van den tijdelijken Emigratie-Agent te Semarang, (6 Mei 1907, Archief Immigratie-Departement) zijn de voornaamste bezwaren van het werven van landbouwersgezinnen de volgende:

1. Gehuwden met kinderen zijn zelden of nooit te bewegen naar Suriname te gaan, omdat de vrouw van een gehuwd paar voor Suriname ook contract moet sluiten.

2. De wervers willen niet graag medewerken tot het aanwerven van gehuwden met kinderen, omdat de kans zeer groot is, dat of de man, of de vrouw, of een der half volwassen kinderen zal worden afgekeurd. In onderling overleg met het Werfagentschap in Oost-Indië en met de plantagebeheerders in Suriname, die overeenkomsten zouden moeten sluiten met niet gecontracteerde Javaansche vrouwen, zullen deze bezwaren - voor zooverre zij nog bestaan - geenszins onoverkomelijk zijn. Vele plantagebeheerders zijn geneigd niet-gecontracteerde vrouwen werk te verschaffen, sommigen doen dit nu zelfs bij voorkeur. $\mathrm{Nu}$ het bovendien langzamerhand duidelijk wordt hoe gering het nuttig effect van de tegenwoordige immigranten is,zullen tegen de hoogere kosten van de gezinswerving wel geen steekhoudende bezwaren geopperd kunnen worden. 


\section{$\S \mathrm{V}$. Aanvulling en correctie}

Volgens de registers van aanvoer en vertrek van NederlandschIndische immigranten in Suriname, bedroeg in de jaren 18901925

het aantal immigranten . . . 15394 mannen, 9368 vrouwen, het aantal teruggekeerden . . . 2027 ” 961 het aantal in Suriname geblevenen 13367 " 8407 ",

Volgens de gegevens van den Burgerlijken Stand bedroeg het aantal Nederlandsch-Indiërs in Suriname op 31 December 1925 . . . . . . 12776 mannen, 9425 vrouwen.

Hieruit zou geconcludeerd moeten worden, dat er gedurende de jaren I890-1925 een sterfte-surplus geweest is van de mannen, groot 59 I en een geboorte-surplus van de vrouwen, groot IoI9. Het totale geboorteoverschot zou dan slechts 427 bedragen.

Zeer terecht werden deze ontstellende cijfers - zooals deze uitkomsten bij een nog immigreerende bevolking genoemd moeten worden - niet zonder meer aanvaard.

Naar aanleiding van dit onderzoek werden dan ook op het Immigratie-Departement alle betreffende registers nageslagen, om de uitkomsten van den Burgerlijken Stand hieraan te toetsen.

De voornaamste conclusies, waartoe de bestudeering van deze cijfers aanleiding geeft, zijn:

1. Vóór 1923 zijn er zeer belangrijke verschillen tusschen het aantal geborenen en het aantal overledenen, zooals dit wordt opgegeven door den Burgerlijken Stand en zooals de Registers van het Immigratie-Departement aanwijzen.

Die verschillen zijn vooral groot in 1906, 1909, 1910, 1920 en 1922.

$\mathrm{Na} 1923$ zijn de cijfers van Burgerlijken Stand en ImmigratieDepartement eensluidend, behalve het aantal overledenen in 1923

2. Het totaal aantal geborenen bedraagt:

volgens den Burgerlijken Stand . . . . . . 6831

volgens het Immigratie-Departement. . . . . 6963

Het totaal aantal overledenen bedraagt:

volgens den Burgerlijken Stand . . . . . . 4782

volgens het Immigratie-Departement . . . . 4936

Het geboorte-overschot bedraagt:

volgens den Burgerlijken Stand . . . . . 2049

West Indische Gids IX 
volgens het Immigratie-Departement . . . . 2027

3. Volgens de gegevens van den Burgerlijken Stand bedroeg het aantal Nederlandsch-Indiërs in Suriname op 31 December 192512776 mannen, 9425 vrouwen, dit is 22201 totaal.

(Dit aantal is verkregen door registratie, gebaseerd op de telling van het jaar 1921).

Vergelijkt men deze uitkomst met het aantal immigranten, dat in Suriname is gekomen en dat niet is teruggekeerd - namelijk 13367 mannen en 8407 vrouwen - dan volgt hieruit, dat er bij de mannen een sterfte-surplus is van 591 en bij de vrouwen een geboorte-overschot van 1018, dit wil zeggen een totaal geboorteoverschot van 427 .

Dit cijfer is derhalve in tegenspraak met de nader verkregen gegevens van den Burgerlijken Stand. Volgens deze gegevens bedraagt het totale geboorte-overschot 2049.

Aangezien de juistheid van het aantal aangevoerde en teruggevoerde immigranten niet betwijfeld kan worden, moet ofwel de uitkomst van de volkstelling in 1921 onjuist zijn, ofwel de registratie van geboorte en sterfte in die mate foutief zijn, dat het geboorte-overschot in plaats van 2049 slechts 427 bedroeg.

Aangezien het aantal geborenen zeker niet kleiner is geweest dan het aantal aangiften bedroeg, zouden dus minstens $1600 \mathrm{Ne}-$ derlandsch-Indiërs méér overleden zijn, dan er in die jaren als overleden zijn aangegeven en geregistreerd.

Uit de overeenkomst van het geboorte-overschot volgens Burgerlijken Stand en Immigratie-Departement behoeft tot de juistheid van die cijfers niet geconcludeerd te worden, omdat de bronnen van fouten dezelfde kunnen zijn.

Het is evenwel moeilijk aan te nemen, dat er zulke grove fouten bij de registratie zijn gemaakt, omdat gedurende de eerste jaren de Nederlandsch-Indische bevolking klein en geheel onder contract verbonden was, terwijl in de latere jaren het Bevolkings-Register bestond.

Vermoedelijk zal zoowel de volkstelling als de registratie van geboorte en sterfte min of meer onjuist zijn.

Hoe groot het geboorte-overschot in werkelijkheid zal zijn, is niet te zeggen.

a. Is de registratie van geboorte en sterfte bij benadering juist, dan bedraagt het geboorte-overschot ongeveer ,20oo"'. Bij de volkstelling zouden dan "I6oo" Nederlandsch-Indiërs niet geteld zijn.

b. Is de volkstelling juist geschied, dan bedraagt het geboorteoverschot ongeveer 4oo". Bij de registratie van geboorte en sterfte zou 
DE NEDERL.-INDISCHE IMMIGRATIE IN SURINAME 483

dan minstens een fout gemaakt zijn van „I60o" overledenen, die niet geboekt zijn (Zuigelingensterfte?)

\section{SLOTWOORD}

In het gunstigste geval,aannemende dat inderdaad bij de volkstelling in 1921,1600 " Nederlandsch-Indiërs aan de aandacht zijn ontsnapt, bedraagt het geboorte-overschot in 35 jaren tijds van geregelden aanvoer van jonge mannen en vrouwen niet meer dan 438 mannen en 1589 vrouwen bij een totale immigranten-bevolking op 31 December 1925, groot 22201 zielen.

Dit uiterst geringe geboorte-overschot wijst er wel op, dat bij een eventueele beëindiging van deze immigratie, dit geboorteoverschot zal plaats maken voor een sterfte-surplus.

Door relatief betere bezetting van de oudere leeftijdsklassen en minder sterke bezetting van de jongere voortbrengingsklassen zal de sterfte zoodanig toenemen en de geboorte zoodanig afnemen, dat - overeenkomstig de vroeger berekende „opgroei-coëfficient" - de Nederlandsch-Indische bevolking in Suriname, aan zich zelve overgelaten, in korten tijd te gronde zal gaan.

Slechts bij betere selectie van de immigranten in Ned.-O.-I. (werving van „dessagezinnen") en bij betere hygiënische verzorging in Suriname, zal de vruchtbaarheid toenemen en de opgroei van dit ras in Suriname zoo groot worden, dat voortgezette immigratie voert tot blijvende kolonis a tie.

II

\section{BESCHOUWINGEN OVER DEN HYGIËNISCHEN TOESTAND IN SURINAME EN BRITSCH-GUYANA}

In Britsch-Guyana heerscht een grootere welstand in het algemeen en een betere ontwikkeling en hoogere beschaving van de vroegere immigranten in het bijzonder. Typeerend is onder andere, dat in Britsch-Guyana de verhouding van de wettig en de niet wettig geboren kinderen uit immigranten-ouders even groot is als van de wettig en niet wettig geboren kinderen uit Inlandsche ouders. 
Tegelijkertijd met dien meerderen welstand in het algemeen en die betere ontwikkeling en hoogere beschaving bij de vroegere immigranten in het bijzonder, vinden wij in Britsch-Guyana, vergeleken met Suriname:

1. een hooger sterfte-cijfer van „Blacks” en „East-Indians”.

2. een grooter percentage levenloosgeboren kinderen bij de „Blacks” en „East-Indians”.

3. een grootere sterfte in het eerste levensjaar bij de „Blacks”, de „Mixed Races” en „East-Indians”.

4. een lager geboorte-cijfer bij de „East-Indians”.

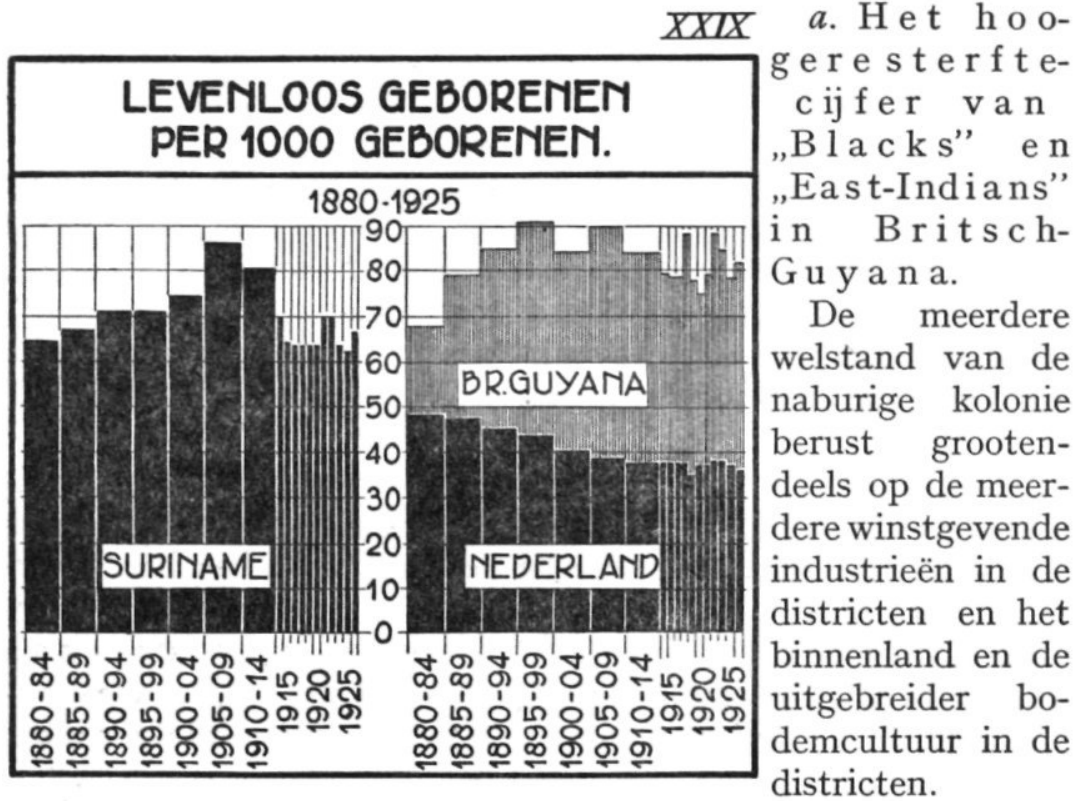

Bij de industrieën wordt de arbeid ter plaatse voornamelijk geleverd door de „Blacks”, bij de cultivatie van den bodem voornamelijk door de „East-Indians”.

Bij de vergelijking van de doodsoorzaken-statistieken van Britsch-Guyana en Suriname en bij de vergelijking van de sterftecijfers aan de voornaamste ziekten is gebleken, dat het hoogere totale sterfte-cijfer van Britsch-Guyana voor een groot gedeelte berust op de grootere sterfte aan malaria, nephritis en pneumoniebronchitis, allemaal ziekten, die bijna uitsluitend bij de uitoefening van de werkzaamheden in de districten en in de binnenlanden worden opgedaan.

(Opmerkelijk is ook, dat in Britsch-Guyana de sterfte aan 


\section{BESCHOUWINGEN OVER DEN HYGIËNISCHEN TOESTAND 485}

tuberculose per 100 overledenen zooveel kleiner is dan in Suriname. Dit kan dan beschouwd worden als een van de weinige goede gevolgen van den meerderen welstand in Britsch-Guyana, mindere concentratie van de bevolking in de stad en betere woningtoestanden aldaar).

Een oorzakelijk verband tusschen de ruimere exploitatie van de binnenlanden en de meerdere cultivatie van den bodem eenerzijds en het grootere sterfte-cijfer van „Blacks” en „East-Indians” anderzijds is dus geenszins onaannemelijk.

$b$. Het grootere percentage levenloosgeboren kinderen en de grootere zuigelingensterftebij de „Blacks” en „East-Indians”

Ook bij dezen factor van den slechten gezondheids-toestand van Britsch-Guyana moet gedacht worden aan de gevolgen van malaria en nephritis en bovendien aan de gevolgen van de venerische infecties, waarvan het voorkomen maar al te vaak in verband staat met meerdere welvaart en ontwikkeling, zooals bij de Britsch-Indiërs in Britsch-Guyana.

c. Het lagere geboorte-cijfer van de Britsche-Indiërs in Britsch-Guyana.

Het lagere geboorte-cijfer van de Britsch-Indiërs in BritschGuyana, vergeleken met het geboorte-cijfer van de Britsch-Indiërs in Suriname, is - gezien de ervaring in de meeste landen van Europa opgedaan na 1880 - zeer waarschijnlijk ook in verband te brengen met den meerderen welstand en de betere ontwikkeling. 
d. B e s lu it.

De - in verhouding tot Suriname - slechte gezondheidstoestand van Britsch-Guyana, zich uitende in een hooger sterftecijfer van "Blacks and East-Indians”, in een grooter percentage levenloosgeboren kinderen bij „Blacks and East-Indians”, in een grootere sterfte in het eerste levensjaar bij „Blacks, Mixed and East Indians” en een lager geboorte-cijfer van de „East-Indians", is als een onmiddellijk gevolg te beschouwen van de meedere exploitatie en de ruimere productie in de binnenlanden en districten van Britsch-Guyana,waar de werkverschaffing nimmer voldoende hygiënisch werd voorbereid.

De betere oeconomische toestand van Britsch-Guyana, op die meerdere exploitatie en ruimere productie gebaseerd, is dus wel duur gekocht.

Het is een waarschuwend voorbeeld voor Suriname, waar dezelfde noodlottige gevolgen van meerdere exploitatie en ruimere productie dreigen, indien de hygiënische voorbereiding van de massale vermeerdering van productieve krachten nog langer zou worden verzuimd.

De meerdere gemiddelde welstand van de bevolking van Suriname zal dan tenslotte wel worden bereikt, maar evenals in Britsch-Guyana ten koste van zware offers, die ieder jaar opnieuw zich zullen doen gelden in den vorm van een groot verlies aan arbeidskracht en een groot verlies aan menschenlevens, die vroegtijdig zullen vallen als slachtoffers van een kortzichtige politiek.

Met nadruk moge hier gewezen worden op het feit - in het tweede gedeelte nader gedocumenteerd -:

1. dat van Overheidswege uitsluitend de individueele ziekenzorg behartigd is en wel op een zeer lofwaardige wijze;

2. dat het Surinaamsche volk (de lagere klassen van de Inlandsche bevolking en de Immigranten) nimmer nog goed geholpen werd, zich te weren tegen tal van ziekten.

3. dat een meer rationeele verdeeling van de belangrijke sommen, die jaarlijks voor de geneeskundige verzorging van Suriname beschikbaar zijn, is aangewezen, in dien zin dat het voorkomen en bestrijden van ziekten meer op den voorgrond en het verzorgen en genezen van zieken van Staatswege meer op den achtergrond wordt geplaatst;

4. dat iedere bezuiniging op de individueele ziekenverzorging, die niet in haar geheel den dienst ter voorkoming en bestrijding van ziekten ten goede komt, slechts in naam een besparing, maar 
in der daad steeds grooter wordend en moeilijker te herstellen verlies zal beteekenen.

Deze beschouwingen vormen een klemmend bewijs te meer voor de stelling, dat een gezonde ontplooiing van den oeconomischen toestand van Suriname slechts mogelijk is, indien van Overheidswege voldoende maatregelen genomen worden tervoorkoming en bestrijding van die ziekten, die bij een werkverschaffing op ruimer schaal in binnenlanden en districten en bij het concentreeren van werkkrachten aldaar, meer nog dan nu den gezondheidstoestand van Suriname zullen bedreigen, van de stelling, dat het Surinamevraagstuk is een vraagstuk van hygienisch voorbereide immigratie.

Slechts op die basis kan een nieuwe toekomst worden gebouwd een nieuwe toekomst, niet alleen van meerdere materieele welvaart, duur gekocht ten koste van den algemeenen gezondheidstoestand, maar een nieuwe toekomst, die zal zijn tot een zegen voor allen, gedragen door een gezond geslacht ${ }^{\mathbf{1}}$ ).

1) Met nadruk wil ik er op wijzen, dat uit de boven medegedeelde bijzonderheden niet geconcludeerd mag worden, dat Suriname een ongezond land zou zijn, of dat in Suriname een ongezond klimaat zou heerschen.

Met meer nadruk nog, wil ik hier ontkennen, dat deze onjuiste meening ooit de mijne zou zijn geweest.

Mijn vaststaande overtuiging is, dat Suriname een gezond land is voor ieder, die zich met enkele voorzorgen tegen bepaalde ziekten kan behoeden en dat het klimaat van Suriname niet alleen aangenaam, maar ook zeer bevorderlijk is voor het behouden van een goeden gezondheidstoestand.

De Europeanen in Suriname en de betere klassen van de Inlandsche bevolking mogen zich dan ook verheugen in een gezondheidstoestand, die zeker niet achtergesteld behoeft te worden bij die in de meest gezonde, gematigde zônes van Europa.

Het zijn de slechte hygiënische toestanden, die gevonden worden bij het overige gedeelte van de bevolking - helaas het overgroote deel - waarvoor ik de aandacht vraag; de slechte hygiënische toestanden bij de gewone Inlandsche bevolking en bij de Immigranten, niet slecht ten gevolge van klimaat of anderszins, maar slecht, omdat deze menschen - paupers en onwetenden - niet in staat zijn en niet in staat gesteld worden zich te te weren tegen bepaalde infectie-ziekten, die ook overal elders ter wereld voorkomen. 